\title{
Spojrzenie na odnowę strategiczną z punktu widzenia długowieczności organizacji
}

\section{The look at the strategic renewal in terms of the organization longevity}

\author{
Jarosław Karpacz ${ }^{\mathrm{a}}$, Bogdan Nogalski ${ }^{\mathrm{b}}$, Anna Wójcik-Karpacz ${ }^{\mathrm{c}}$ \\ ${ }^{a}$ Uniwersytet Jana Kochanowskiego w Kielcach, e-mail: j.karpacz@ujk.edu.pl \\ ${ }^{b}$ Uniwersytet Gdański, e-mail: nogalski@wzr.ug.edu.pl \\ ${ }^{c}$ Uniwersytet Jana Kochanowskiego w Kielcach, e-mail: anna.karpacz@interia.pl
}

\begin{abstract}
Streszczenie
Celem opracowania są rozważania o odnowie strategicznej jako mechanizmie używanym do dopasowania organizacji do zmian otoczenia, co leży u podłoża długowieczności organizacji. Przegląd wybranych fragmentów literatury z zakresu zarządzania strategicznego i przedsiębiorczości umożliwił identyfikację osadzenia odnowy strategicznej w przedsiębiorczości organizacyjnej. Zaprezentowano także naturę odnowy strategicznej organizacji wraz ze wskazaniem odpowiedniej infrastruktury menedżerskiej jako determinanty pozytywnych efektów implementacji odnowy w praktyce. W opracowaniu przedstawiono przykłady długowiecznych przedsiębiorstw, w których wielokrotnie z sukcesem dokonywano odnowy strategicznej. Wskazano również przykład przedsiębiorstwa, w którym odnowa nie przyniosła oczekiwanych rezultatów, w efekcie czego przedsiębiorstwo zostało zlikwidowane.
\end{abstract}

Słowa kluczowe: odnowa strategiczna, przedsiębiorczość, zarządzanie strategiczne.

\begin{abstract}
The aim of the paper is the reflection on the strategic renewal as a mechanism used to align the organization to the changing environment, which underlies the longevity of the organization. The review of selected literature in the field of strategic management and entrepreneurship enabled the identification of embedding the strategic renewal within the organizational entrepreneurship. The paper also presents the nature of the strategic renewal, indicating adequate managerial infrastructure as a determinant of positive effects of the strategic renewal implementation in practice. The paper presents examples of long-lived enterprises, which repeatedly has successfully made the strategic renewal. It also points out the example of an enterprise in which the renewal did not bring the expected results, and consequently, the enterprise was liquidated.
\end{abstract}

Keywords: strategic renewal, entrepreneurship, strategic management. 


\section{Wstęp}

W dynamicznym otoczeniu przedsiębiorczość organizacyjna odgrywa rolę mechanizmu izolującego, zwiększającego trwałość przewagi konkurencyjnej wtedy, gdy ma wbudowaną zdolność do zmiany konfiguracji nośników procesowych i strukturalnych zgodnie z naturą współewoluowania organizacji wraz z otoczeniem [Bratnicki 2008, s. 7-20]. Przedsiębiorczość organizacyjna jest potencjalną strategią przetrwania dla przedsiębiorstw działających w wysoce konkurencyjnym otoczeniu. Jest ona szczególnie zalecana dla uznanych przedsiębiorstw, które stoją w obliczu spadku efektywności i chcą zmienić ten stan.

Pojęcie przedsiębiorczości organizacyjnej obejmuje akty tworzenia organizacyjnego, odnowy i innowacji niezależnie od kontekstu. W procesie przedsiębiorczości następuje przekształcenie, w sposób proaktywny i przezwyciężający ryzyko, pomysłu w przedsięwzięcie mające wysokie prawdopodobieństwo przetrwania dzięki tworzeniu i wykorzystywaniu szans [Dyduch 2008, s. 20]. Szansa to rozbieżność w dostrzeganym, ciągle zmieniającym się krajobrazie i czasoobrazie, niewykorzystywana przez innych, którą można wypełnić dzięki dostarczeniu odbiorcom więcej wartości niż dotychczas [Bratnicki 2002, s. 138].

Rozprzestrzeniający się dynamizm i niepewność w burzliwym otoczeniu wymagają od przedsiębiorstw rozwijania kompetencji i działania w sposób strategiczny. Ponieważ przedsiębiorczość to identyfikowanie i wykorzystywanie szans oraz kreowanie niepewności wskutek rozważania dużej liczby nowych idei i wariantów decyzyjnych, niezbędne staje się myślenie zarówno w sposób przedsiębiorczy, jak i strategiczny [Dyduch 2008, s. 20]. Niezbywalnym składnikiem tak zakreślonego pola przedsiębiorczości organizacyjnej jest odnowa strategiczna. Przedsiębiorczość organizacyjna nakazuje, by w celu odzyskania przewagi konkurencyjnej zasadniczo odnowić przedsiębiorstwo [Covin, Miles 1999, s. 47-63]. Celem opracowania są rozważania o odnowie strategicznej jako mechanizmie dopasowującym organizację do zmian otoczenia, co leży u podstaw długowieczności organizacji.

\section{Osadzenie odnowy strategicznej w teorii przedsiębiorczości organizacyjnej}

Przedsiębiorczość organizacyjna jest integralną częścią strategicznego zarządzania organizacją. Polega ona na strategicznym ukierunkowaniu na rozwój, chęci do podejmowania wyważonego ryzyka, tolerancji nieokreśloności, uczeniu się na porażkach, promowaniu elastyczności, twórczości, innowacji oraz na odnowie strategicznej [Bratnicki 2009, s. 49-62].

Przedsiębiorczość organizacyjna obejmuje trzy główne składniki: innowacje, odnowę strategiczną i nowe przedsięwzięcia [Zahra 1995, s. 225-247].

Innowacja dotyczy tworzenia i wprowadzania nowych produktów, procesów produkcyjnych i systemów organizacyjnych. Odnosi się ona także do nowych modeli biznesowych, które opisują, w jaki sposób organizacja projektuje i przeprowadza wymiany ekonomiczne poprzez granice oraz w jaki sposób wiąże zasoby i rynki produktowe w poszukiwaniu bogactwa. Innowacja to coś więcej niż nowatorski pomysł, to proces, który obejmuje opracowanie koncepcji użytkowej produktu lub usługi, aby zdobyć przewagę konkurencyjną na rynku [Yang 2012, s. 34-46]. Odzwierciedla ona kulturę wzrostu organizacji, w tym zobowiązanie do uczenia się i skłonność do podejmowania ryzyka [Yang 2012, s. 34-46]. Z reguły nie można przewidzieć ani źródeł, ani okazji do podjęcia działań innowacyjnych. W związku z tym innowacje w swej naturze są niepewne, trudne do uchwycenia i rozpowszechnienia, kontrowersyjne i przenikają wiele funkcjonalnych obszarów organizacji [Dyduch 2013, s. 67].

Nowe przedsięwzięcia dotyczą wchodzenia w nowe biznesy poprzez tworzenie lub zakup nowych organizacji [Teng 2007, s. 119-142], rozwijanie nowych kompetencji organizacji, utrzymywanie organizacji w stanie czujności wobec szans [Bratnicki 2007, s. 61]. Tworzenie nowego przedsięwzięcia składa się z trzech komponentów: organizowania wokół wizji doprowadzającej do nowej idei biznesu, strategicznego zapewnienia żywotności przedsięwzięcia oraz taktycznego rozpoczynania działalności [Lichtenstein, Dooley, Lumpkin 2006, s. 153-175]. Dzięki tym działaniom w procesie przedsiębiorczości następuje przekształcenie idei w żywotny biznes w sposób proaktywny i przezwyciężający ryzyko, bez zwlekania z tworzeniem, odkrywaniem i wykorzystywaniem szans [Bratnicki 2007, s. 61]. Jednym z kluczowych czynników dla tworzenia nowych przedsięwzięć jest chęć szybkiego wzrostu i wykorzystania szans na nowych rynkach, które są nieosiągalne dla obecnej organizacji.

Natomiast odnowa strategiczna oznacza transformację przedsiębiorstwa lub rewitalizację jego funkcjonowania poprzez zmianę dziedziny działalności, sposobu konkurowania albo obie te zmiany łącznie [Zahra 1996, s. 1713-1735]. Odnowa odzwierciedla różnorodne aktywności zmierzające do ożywienia działalności organizacji, do zbudowania nowych zdolności konkurencyjnych czy też do zmiany ciągu strategicznego w sposób fundamentalny - a więc przeobrażający zasadniczo bazę technologiczną, rewidujący systemy i procesy, stawiając wyzwania wobec dotychczasowych założeń o rynku i konkurencji [Bratnicki 2007, s. 61].

Według istniejących konceptualizacji konstrukty „nowe przedsięwzięcia” i „odnowa strategiczna” mają kilka ważnych podobieństw [Covin, Lumpkin 2011, s. 855-872], które, odnosząc się do przedsiębiorczości organizacyjnej, są związane z innowacjami, a także powodują zmiany zarówno w strategii, jak i strukturze organizacji [Sharma, Chrisman 1999, s. 11-27]. Jednakże nowa działalność nie jest warunkiem koniecznym odnowy [Basu, Wadhwa 2013, s. 956-975]. Odnowa powoduje zasadnicze zmiany w istniejących sposobach, w jakich przedsiębiorstwo prowadzi swoją działalność, w jego modelu biznesu, strategii i strukturze [Huff, Huff, Thomas 1992, s. 55-75]. W przeciwieństwie do nowych przedsięwzięć, odnowa odbywa się tylko wtedy, gdy rdzeń biznesu przechodzi znaczące zmiany. Odnowa to proces, który może mieć krytyczny wpływ na organizację, na jej długoterminowe perspektywy, generując zasadnicze zmiany w kluczowych atrybutach organizacji [Basu, Wadhwa 2013]. 
Dotychczasowe badania empiryczne [Eisenhardt, Tabrizi 1995, s. 84-110; Helfat, Raubitschek 2000, s. 961-979] skupiały się głównie na szybkości i częstotliwości innowacji produktowych i procesowych i nie uwzględniały działań związanych z odnową strategiczną całej organizacji, co odsłania pole dalszych dociekań naukowych.

\section{Natura odnowy strategicznej}

Głównymi pojęciami w badaniach prowadzonych w ramach zarządzania strategicznego oprócz rentowności i przewagi konkurencyjnej jest długoterminowe przeżycie w dynamicznym dopasowaniu między organizacją a jej otoczeniem [Ben-Menahem et al. 2013, s. 216-235]. W literaturze wskazuje się dwie alternatywne perspektywy teoretyczne na temat dopasowania: wyboru (selekcji) otoczenia i organizacyjnej adaptacji. Główna różnica pomiędzy tymi punktami widzenia leży w zakresie, w jakim przedsiębiorstwa mogą się odnawiać wobec zmian otoczenia.

Sugeruje to, że organizacje mogą najlepiej dopasować się do szans i zagrożeń pojawiających się w ich środowisku zewnętrznym poprzez wewnętrzną odnowę strategiczną. U podstaw tego twierdzenia leży szeroka debata na temat tego, czy organizacje mogą samodzielnie odnawiać się w celu utrzymania takiego dynamicznego dopasowania w czasie. Podczas gdy jeden strumień badań sugeruje, że organizacje nie są w stanie się zmieniać, drugi wskazuje na liczne przykłady długowiecznych organizacji, wskazując, że organizacje mogą być w stanie utrzymać swoją przewagę konkurencyjną w obliczu zmian poprzez odnowę strategiczną [Ben-Menahem et al. 2013].

Przyjmując perspektywę adaptacji, można stwierdzić, że odnowa strategiczna może zostać osiągnięta poprzez intencjonalne zarządzanie zmianami. Natomiast głównym zadaniem menedżerów jest wyzwolenie zdolności do absorpcji nowej wiedzy.

Powodzenie organizacji, mierzone stopniem realizacji zakładanej strategii rozwoju, zależy od umiejętności dynamicznego dostosowania organizacji do zmieniających się warunków otoczenia [Cyfert 2012, s. 123-130]. Oprócz zmiany strategii w odpowiedzi na zmiany zewnętrzne, zarządzający próbują dostosowywać otoczenie przedsiębiorstwa pod kątem jego własnych korzyści. Oznacza to, że przedsiębiorstwa mogą zachowywać się proaktywnie, dopasowując do siebie otoczenie przedsiębiorstwa [Eisenhardt, Martin 2000, s. 1105-1121]. Łącząc perspektywy selekcji i adaptacji otoczenia, stwierdzono, że ciągła odnowa strategiczna wymaga, aby szybkość działań odnowy strategicznej była dostosowana przez cały czas do tempa zmian w otoczeniu zewnętrznym [Karpacz 2011, s. 39-41]. Jednak ten ważny wymiar odnowy strategicznej nie jest dostatecznie zbadany. Istniejące badania zwykle sugerują, ze tempo zmian w otoczeniu zewnętrznym organizacji silnie wpływa na tempo wewnętrznych operacji i procesów. Dlatego niektórzy badacze sugerują, że wewnętrzne i zewnętrzne zmiany koewoluują [Ben-Menahem et al. 2013].

W literaturze podkreśla się wieloaspektowy i ewolucyjny charakter odnowy strategicznej [Agarwal, Helfat 2009, s. 281-293], przyznając, że odnowa strategiczna nie tylko jest inicjowana przez proces przedsiębiorczości, lecz także może być powiązana ze specyficznymi wynikami. Za takie uznaje się rekonfigurację istniejących biznesów, a także przejście od istniejących i znanych działalności do nowszych i mniej znanych [Crossan, Berdrow 1993, s. 77-103; Mezias, Glynn 1993, s. 77$-101]$.

Odnowa strategiczna wiąże się z natury z niepewnymi rezultatami, ponieważ często jej realizacja wymaga rezygnacji ze znacznie bardziej pewnych korzyści wynikających z posiadanych kompetencji [Agarwal, Helfat 2009]. Jednak przedsiębiorstwa wchodzą na ścieżkę odnowy, ponieważ menedżerowie uznają ją za konieczną, aby móc wykorzystać szanse [Dess et al. 2008, s. s. 351-378]. Dokonywanie przedsiębiorczych wyborów ma sens tylko wtedy, kiedy wierzy się, że wpłyną one na bieg zdarzeń [Bratnicki 2009, s. 49-62].

Wyniki badań różnych wymiarów odnowy strategicznej sugerują, że organizacje, przystępując do odnowy, mają dostępnych wiele różnych dróg jej przeprowadzenia. W celu uzyskania odnowy podejmowane są działania w zakresie badań i rozwoju [Knott, Posen 2009, s. 352-367], zewnętrznych źródeł [Capron, Mitchell 2009, s. 294-312] i innowacji produktowych [Kim, Pennings 2009, s. 368-383]. Chociaż badania te dostarczają cennych informacji na temat procesów organizacyjnych, które mogą prowadzić do odnowy strategicznej, często jednak nie obejmują swym zasięgiem bezpośrednio tego, czy odnowa ta ma miejsce.

Nieciągła odnowa strategiczna, która pociąga za sobą zmiany podstawowych biznesów na nowsze i bardziej nieznane (mniej znane), jest obarczona znaczną niepewnością. Mimo to przedsiębiorstwa decydujące się na odnowę rezygnują z bardziej pewnych korzyści z istniejących biznesów, wierząc, że odnowa przedsiębiorstwa będzie lepszym rozwiązaniem [Floyd, Lane 2000, s. 154-177].

Taka odnowa obejmuje więcej eksploracji niż eksploatacji. Eksploracja jest definiowana jako rozwój nowych i nieznanych kompetencji, a eksploatacja jako realizacja korzyści z istniejących i znanych kompetencji [Levinthal, March 1993, s. 95-112]. Dlatego odnowa nieciągła jest zasadniczo bardziej niepewna niż odnowa inkrementalna w ramach istniejących biznesów lub wewnętrznych i zewnętrznych nowych przedsięwzięć, gdzie eksploracja i eksploatacja występują jednocześnie.

W efekcie nieciągłej odnowy przedsiębiorstwo może nie rozwinąć kompetencji niezbędnych do efektywnego konkurowania w nowym kluczowym biznesie, nawet jeśli posiadało kompetencje, które dobrze służyły w poprzednim kluczowym biznesie, tym samym zagrażając jego przetrwaniu.

Przedsiębiorstwo, podejmując się odnowienia, może nie rozwinąć kompetencji niezbędnych do skutecznego konkurowania w nowej działalności podstawowej, nawet jeśli wykorzysta kompetencje, które przynosiły korzyści w dotychczasowej (starej) działalności podstawowej. Literatura dostarcza zarówno pozytywnych, jak i negatywnych przykładów odnowy.

Przykładem pozytywnego przesunięcia kompetencji jest firma Intel, która w ten sposób z bycia liderem w produkcji kości pamięci stała się pionierem $\mathrm{w}$ produkcji mikroprocesorów. Z kolei za przykład nieudanego przeniesienia kompetencji może 
posłużyć firma Polaroid, która mimo znaczących wysiłków nie potrafiła przestawić się na nowy i bardziej atrakcyjny model biznesu. Przykład Polaroida jest o tyle ciekawy, że Polaroid nie odnalazł się na rynku fotografii cyfrowej, mimo że był jednym z pierwszych producentów aparatów cyfrowych. Jednakże rosnąca popularność aparatów cyfrowych spowodowała, że popyt na produkty fotografii tradycyjnej gwałtownie spadł. Polaroid został zmuszony do ogłoszenia upadłości w 2001 roku i został przejęty przez Bank One. Ostatecznie produkcję aparatów polaroid zakończono w 2007 roku, a filmów (wkładów) w 2009 roku [Basu, Wadhwa 2013].

Jednak pomimo ryzyka związanego z nieciągłą odnową strategiczną istnieją silne bodźce i presja wywierana na organizacje realizujące takie okresowe inicjatywy i odchodzące od istniejących kluczowych biznesów. Przedsiębiorstwa rozpoczynają odnowę nieciągłą, gdy ich menedżerowie rozpoznają wyzwania związane z konkurencją w starych i nowych biznesach jednocześnie. Po pierwsze, przedsiębiorstwa, istniejąc w kluczowym biznesie, mogą być konkurencyjne w branżach, w których istnieje prawdopodobieństwo zagrożenia zintensyfikowania konkurencji w najbliższej przyszłości, a tym samym ograniczenia zysków [Dess et al. 2003, s. 351-378]. Po drugie, firma mogłaby skuteczniej konkurować w potencjalnie dochodowym biznesie poprzez wprowadzenie większej ilości zasobów do tych biznesów, niż poprzez rozłożenie ich na stare i nowe biznesy [Mezias, Glynn 1993, s. 77-191]. Po trzecie, okresowo podejmowana odnowa może wspomagać budowanie kultury adaptacyjnej w przedsiębiorstwie, które ma możliwość rozpoznawania i reagowania na przyszłe zagrożenia, dzięki czemu może przezwyciężyć inercję [Floyd, Lane 2000, s. 154-177].

Zgodnie z tymi argumentami, długowieczne firmy, takie jak 3M, General Electric i IBM, odnowiły ich podstawowe biznesy kilkakrotnie $\mathrm{w}$ ich historii.

Firma 3M została powołana do życia w 1902 roku w stanie Minnesota. Założyło ją pięciu biznesmenów, którzy podjęli decyzję o eksploatacji złóż mineralnych na potrzeby materiałów ściernych dla ściernic. Okazało się jednak, iż złoża miały niewielką wartość i w 1905 roku firma Minnesota Mining and Manufacturing przeniosła się do pobliskiego Duluth, aby skoncentrować się na produkcji papieru ściernego. Po latach zmagań firmie udało się rozpocząć produkcję wysokiej jakości. Fakt ten przyciągnął do 3M nowych inwestorów i w 1910 roku firma przeniosła się do St. Paul. Wczesne innowacje w dziedzinie techniki i marketingu zaowocowały pierwszymi sukcesami - w 1916 roku firma wypłaciła pierwszą dywidendę w wysokości 6 centów za 1 akcję. Na początku lat 20. XX wieku opracowano pierwszy na świecie wodoodporny papier ścierny, który zmniejszał ilość pyłu zawieszonego w powietrzu podczas produkcji samochodów. Drugie doniosłe wydarzenie miało miejsce w 1925 roku, kiedy młody laborant Richard G. Drew wynalazł taśmę maskującą, stanowiącą nowatorski krok w kierunku zróżnicowania produktów oraz będącą pierwszą z wielu taśm samoprzylepnych marki Scotch. W kolejnych latach postęp techniczny zaowocował opracowaniem celofanowej taśmy Scotch
Cellophane Tape służącej do zamykania i opieczętowywania kartonów - niedługo po tym odkryto setki jej praktycznych zastosowań. We wczesnych latach 40 . XX wieku działalność 3M skierowano na produkcję materiałów obronnych na potrzeby II wojny światowej. Po tym okresie powstały nowe projekty, takie jak folie odblaskowe Scotchlite wykorzystywane do oznakowywania dróg, taśma magnetyczna zapisująca dźwięk i taśma klejąca z włókien. Wówczas także firma 3M po raz pierwszy zaangażowała się w branżę graficzną, produkując klisze do druku offsetowego. W latach 50. firma 3M wprowadziła proces kopiowania Thermo-Fax ${ }^{\mathrm{TM}}$, powłokę ochronną dla tkanin Scotchgard, taśmę wideo, wkładki czyszczące Scotch-Brite ${ }^{\circledR}$ oraz wiele nowych produktów elektromechanicznych. W latach 60 . wypuszczono na rynek mikrofilm wykonany w technologii suchego srebra, następnie produkty fotograficzne, rzutniki pisma, a także produkty medyczne i stomatologiczne w ramach szybko rozwijającego się sektora opieki zdrowotnej. W latach 70. i 80. nastąpiło dalsze poszerzenie działalności i wejście na rynek środków farmaceutycznych, radiologii, kontroli energii, materiałów biurowych, przy jednoczesnej ekspansji geograficznej i objęciu swoim zasięgiem niemal wszystkich krajów na świecie. W latach 90. firma 3M w dalszym ciągu opracowywała szeroką gamę nowatorskich produktów, takich jak środki farmaceutyczne modyfikujące reakcję immunologiczną, folie poprawiające jasność obrazu wyświetlaczy elektronicznych, a także elastyczne obwody elektroniczne na taśmie wykorzystywane w drukarkach atramentowych, telefonach komórkowych i innych urządzeniach elektronicznych. Lata dziewięćdziesiąte XX wieku to także pojawienie się na rynku filtra 3M Privacy Plus, pierwszego elementu wyposażenia ekranów komputerowych, łączącego prywatność, właściwości przeciwodblaskowe i ochronę przed promieniowaniem, pierwszego na świecie niezawierającego freonów inhalatora dla osób chorych na astmę, a także materiałów ściernych o specjalnej strukturze (wyprodukowanych na bazie opatentowanej przez $3 \mathrm{M}$ technologii mikroreplikacji). Najnowsze z nowatorskich rozwiązań obejmują: karteczki samoprzylepne Post-it Super Sticky, przezroczystą taśmę klejącą Scotch Transparent Duct, optyczne folie dla telewizorów LCD, a także nową rodzinę produktów do utrzymania czystości Scotch-Brite, które są doskonałym rozwiązaniem dla klientów poszukujących uniwersalnych środków do czyszczenia ${ }^{1}$.

Z kolei General Electric (GE) została założona przez Thomasa Edisona jako spółka energetyczna w 1892 roku. W 1970 roku stała się dominującym producentem maszyn i silników, a następnie została przekształcona w przedsiębiorstwo działające w różnych branżach. Dzisiaj korporacja GE zajmuje się energetyką ( $w$ tym atomową), ale działa także $w$ takich dziedzinach gospodarki, jak przemysł lotniczy, przemysł kosmiczny, przemysł chemiczny, medyczny czy bankowość. Posiada również 49\% udziałów w wytwórni filmowej NBC Universal. Obecnie należy do największych na świecie producentów turbin energetycznych i silników odrzutowych, odgrywa przodującą rolę w branży sprzętu medycznego, a finansowe ramię korporacji - GE Capital konkuruje z największymi bankami w finansowaniu średnich przedsiębiorstw i emisji kart kredytowych ${ }^{2}$.

\footnotetext{
${ }^{1}$ Opracowano na podstawie materiałów firmy 3M, www.solutions.3mpoland.pl.

${ }^{2}$ Opracowano na podstawie: www.ge.com.pl; www.brandingmonitor.pl.
} 
IBM została utworzona w 1911 roku jako firma mająca w swojej ofercie produktowej wagi, systemy pomiaru czasu pracy, krajalnice do mięsa i karty perforowane. Jednak od 1924 roku kojarzona była z maszynami liczącymi, a od 1948 roku z pierwszym komputerem, który był w stanie modyfikować wprowadzone oprogramowanie. I tak przez pozostałe lata przedsiębiorstwo związane było z komputerami, które wspomagały różnorodne dziedziny życia (transport, medycynę, edukację, handel - nawet kody kreskowe na towarach). W 1981 roku firma zaprezentowała pierwszy komputer klasy PC - IBM 5150, a przez kolejne kilkanaście lat pojęcie pecet kojarzone było właśnie z IBM. W roku 1992 pojawiły się notebooki z serii Thinkpad. Produkujący je dział PC w roku 2005 sprzedano firmie Lenovo ${ }^{3}$. Obecnie IMB czerpie korzyści z patentów i skupia się na biznesie elektronicznym, usługach, oprogramowaniu i tworzeniu superkomputerów. To przykład przedsiębiorstwa, które w momencie, gdy straciło swoją dominację na rynku komputerów, przekształciło się w czołowego dostawcę usług informacyjnych [Basu, Wadhwa 2013].

Jednak dla większości przedsiębiorstw częstotliwość nieciągłej odnowy jest mała, a czas trwania między dwoma takimi działaniami odległy, co wskazuje na znaczne związane z nią trudności. Po pierwsze, niektóre zmiany w otoczeniu zewnętrznym są trudne do przewidzenia. Po drugie, trudno jest skutecznie zarządzać ciągłą adaptacją, ponieważ stoi to w sprzeczności z nawykami pozwalającymi przedsiębiorstwu efektywnie wykonywać bieżące zadania. Ich przezwyciężanie może nastąpić poprzez zinstytucjonalizowanie ciągłej odnowy poprzez nawyki, strukturę organizacyjną i wprowadzenie zachęt do bezustannego podejmowania wysiłku odnowy [Bełz, Krzemiński 2014, s. 11-18].

Uzyskanie pozytywnego wpływu przedsiębiorczości wymaga stworzenia odpowiedniej menedżerskiej infrastruktury, wzmacniającej przedsiębiorcze zachowania za pomocą wielu zmiennych organizacyjnych, z których część jest nie do końca zrozumiała [Bratnicki 2007, s. 63]. W literaturze podkreśla się, że menedżerowie są najważniejszymi agentami odnowy organizacji, a swoją rolę artykułują w działaniu, biorąc odpowiedzialność za określenie czasu, w jakim powinna nastąpić odnowa, a następnie za jej efektywne przeprowadzenie. Częstokroć, aby rozpoznać potrzebę odnowy, menedżerowie muszą zmienić swoje modele mentalne, które są często trudne do zmiany w stabilnych środowiskach. Muszą zatem wyczuwać i interpretować informacje dotyczące zmian w otoczeniu. Menedżerowie są bardziej skłonni do uznania potrzeby odnowy strategicznej i zmiany „dominującej logiki” w ich przedsiębiorstwach, gdy:

- $\quad$ są niezadowoleni z obecnej sytuacji ich przedsiębiorstwa [Huff, Huff, Thomas 1992, s. 55-75],

- koncentrują się na wschodzących, a nie istniejących technologiach [Eggers, Kaplan 2009, s. 461-477],

zajmują bardziej centralną pozycję w wewnętrznej sieci przedsiębiorstwa, co daje im większy dostęp do krytycznych informacji o środowisku [Pappas, Wooldgridge 2007, s. $323-341$.
Menedżerowie, aby móc efektywnie realizować odnowę strategiczną, muszą pokonać konflikty, które pojawiają się wraz z rozwijaniem nowych kompetencji niezbędnych do odnowy i odpowiedniej modyfikacji istniejących kompetencji [Floyd, Lane 2000, s. 154-177]. Muszą również ograniczyć stosowanie formalnej kontroli i systemów nagradzania, które mogą utrudniać implementację odnowy [Poskela, Martinsuo 2009, s. 671-684]. Zamiast tego muszą podkreślać wspólne przekonania i wartości [Simons 1994, s. 169-189] oraz identyfikować odpowiednie zachęty wewnętrzne i zewnętrzne do pozyskiwania nowej wiedzy i zdolności [Capron, Mitchell 2009, s. 294-312].

Badania wykazują, że przedsiębiorstwa wykorzystują innowacje i odnowę strategiczną w celu przechwycenia dostrzeżonych szans [Sáez-Martínez, González-Moreno 2011, s. 43-55]. Dowodzi to, że odnowa strategiczna ma strategiczne i organizacyjne konotacje zmian i wymaga ponownego zdefiniowania koncepcji biznesowej, reorganizacji oraz wprowadzenia systemu szerokich zmian w zakresie innowacji [Zahra 1993, s. 319-340].

Odnowa strategiczna jest działaniem intencjonalnym. Dokonywana jest poprzez wprowadzanie nowych produktów i wchodzenie na nowe rynki, organizacyjne odmładzanie za pomocą wprowadzania nowych procesów albo przekształcania procesów już istniejących, strategiczne transformowanie w celu zespolenia z otoczeniem, a także redefiniowanie domeny przez kreowanie nowych obszarów produkt-rynek [Bratnicki 2007, s. 63].

Najogólniej rzecz ujmując, odnowa strategiczna oznacza działania podejmowane przez przedsiębiorstwo na rzecz zmiany jego ścieżki zależności [Ben-Menahem et al. 2013, s. 216-235]. Takie rozumienie odnowy odnosi się do przedsiębiorczości organizacyjnej i wskazuje na istotne zmiany w strategii danej organizacji lub jego strukturze oraz na modyfikację działań w ramach istniejącej organizacji.

Odnowa nie jest wprowadzaniem pojedynczych zmian dostosowawczych mających na celu dopasowanie do krótkookresowych fluktuacji i zaburzeń w otoczeniu lub w obrębie przedsiębiorstwa, nie jest też usprawnieniem czy racjonalizacją jego działań dokonanych jedynie w jakimś obszarze. Ma charakter strategiczny, gdyż odnosi się do długoterminowej perspektywy funkcjonowania organizacji i ma decydujący wpływ na jej sukces lub porażkę [Agarwal, Helfat 2009].

Odnowa strategiczna dotyczy wszystkich organizacji w różnym wieku i wielkości. Aby to osiągnąć, przedsiębiorstwa muszą wyrwać się z pułapki kompetencji, pozostając w dynamicznym trybie budowania zdolności i stałego odnawiania się poprzez rozpoznawanie szans pojawiających się w ich otoczeniu. Innymi słowy, kluczowe dla powodzenia odnowy strategicznej przedsiębiorstwa jest budowanie zdolności pozwalających uniknąć uwięzienia we własnym sukcesie [Agarwal et al. 2012, s. 710-733].

Z punktu widzenia teorii zarządzania strategicznego odnowa strategiczna jest jedną (obok strategicznej transformacji) z postaci odnowy organizacyjnej [Bełz 2012, s. 19-22]. Odnowa organizacyjna stanowi treść, proces i efekt przekształceń klu-

\footnotetext{
${ }^{3}$ Opracowano na podstawie: www.benchmark.pl.
} 
czowych elementów systemu zarządzania warunkowanych zmianami modelu biznesowego. W rezultacie procesu odnowy organizacyjnej zarządzający organizacją, dążąc do osiągnięcia nowego poziomu równowagi, przekształcają system zarządzania, uwzględniając wymagania zdefiniowane w modelu biznesowym [Cyfert, Bełz, Wawrzynek 2014, s. 15-27].

\section{Podsumowanie}

Pomimo że względnie dużo wiadomo na temat ryzyka i korzyści wynikających z przeprowadzenia odnowy strategicznej, niewiele jest badań warunków, które skłaniają przedsiębiorstwa do podjęcia odnowy strategicznej. Zatem niewiele wiadomo na temat warunków, w których podejmują się one odnowy.

Z kolei, podczas gdy badacze analizowali różne rodzaje nowych przedsięwzięć podejmowanych przez przedsiębiorstwa [Guth, Grinsberg 1990, s. 5-15; Miles, Covin 2002, s. 21-40; Sharma, Chrisman 1999, s. 11-27; Zahra 1993, s. 319-340], wiedza na temat różnych typów i wymiarów odnowy strategicznej ciągle jest ograniczona. Niezbędne wydaje się przeprowadzenie badań, które pozwoliłyby odróżnić rodzaje efektów odnowy i zrozumieć czynniki skłaniające do konkretnych jej form. Dotyczy to szczególnie zaangażowania w zmianę kluczowej działalności przedsiębiorstwa, co powinno być lepiej zrozumiane $\mathrm{z}$ uwagi na wysokie ryzyko związane $\mathrm{z}$ takim działaniem. Istniejące zatem wyniki badań oferują ograniczoną wiedzę na temat realizacji różnych rodzajów odnowy, które mogą być realizowane przez przedsiębiorstwa lub różne ich szczeble organizacyjne. Na przykład przedsiębiorstwo może stopniowo odnawiać swoją wiedzę, doświadczenie i orientację strategiczną $\mathrm{w}$ przedsiębiorstwie. $\mathrm{W}$ innych sytuacjach przedsiębiorstwa mogą prowadzić bardziej fundamentalną i nieciągłą formę odnowy strategicznej, która obejmuje zmiany w jego kluczowej domenie produktowej [Basu, Wadhwa 2013, s. 965-975].

\section{Literatura}

Agarwal R., Anand J., Bercovitz J., Croson R., 2012, Spillovers across organizational architectures: The role of prior resource allocation and communication in post-acquisition coordination outcomes, Strategic Management Journal, vol. 33.

Agarwal R., Helfat C.E., 2009, Strategic renewal of organizations, Organization Science, vol. 20.

Basu S., Wadhwa A., 2013, External venturing and discontinuous strategic renewal: An options perspective, Journal Production Innovation Management, vol. 30.

Bełz G., 2012, Potencjał dostosowawczy w procesach odnowy przedsiębiorstw, Przegląd Organizacji, nr 11.

Bełz G., Krzemiński A., 2014, Zarzadcze struktury sieciowe w procesie odnowy przedsiębiorstw, Marketing i Rynek, nr 5.

Ben-Menahem S.M., Kwee Z., Volberda H.W., van den Bosch F.A.J., 2013, Strategic Renewal Over Time: The enabling role of potential absorptive capacity in aligning internal and external rates of change, Long Range Planning, vol. 46.

Bratnicki M., 2007, Renta przedsiębiorczości w statycznych i dynamicznych otoczeniach, [w:] Przedsiębiorczy menedżer w przedsiębiorczej organizacji, Antoszkiewicz J. (red.), Oficyna Wydawnicza SGH, Warszawa.
Bratnicki M., 2002, Strategia przedsiębiorczości jako przestankowana ekstaza organizacyjna, [w:] Zarządzanie strategiczne. Badania i koncepcje, R. Krupski (red.), Prace Naukowe Wałbrzyskiej Wyższej Szkoły Zarządzania i Przedsiębiorczości, Wałbrzych.

Bratnicki M., 2009, Strategiczna rola przedsiębiorczości w kształtowaniu rozwoju organizacji, [w:] Zarządzanie strategiczne. Problemy, kierunki badań, R. Krupski (red.), Prace Naukowe Wałbrzyskiej Wyższej Szkoły Zarządzania i Przedsiębiorczości, Wałbrzych.

Bratnicki M., 2008, Zarys konceptualnej teorii przedsiębiorczości organizacyjnej, Organizacja i Kierowanie, nr 2.

Capron L., Mitchell W., 2009, Selection capability: How capability gaps and internal social frictions affect internal and external strategic renewal, Organization Science, vol. 20.

Covin J.G., Lumpkin G.T., 2011, Entrepreneurial orientation theory and research: Reflections on a needed construct, Entrepreneurship. Theory and Practice, no 8.

Covin J.G., Miles M.P., 1999, Corporate entrepreneurship and the pursuit of competitive advantage, Entrepreneurship Theory and Practice, vol. 23.

Crossan M.M., Berdrow I., 2003, Organizational learning and strategic renewal, Strategic Management Journal, vol. 24.

Cyfert Sz., Bełz G., Wawrzynek Ł., 2014, Wpływ burzliwości otoczenia na efektywność procesów odnowy strategicznej, Organizacja i Kierowanie, $\mathrm{nr} 1 \mathrm{~A}$.

Cyfert Sz., 2012, Systemowy model organizacji: perspektywa procesów odnowy strategicznej, Prace Naukowe Uniwersytetu Ekonomicznego we Wrocławiu, nr 276.

Dess G.G., Ireland R.D., Zahra S.A., Floyd S.W., Janney J.J., Lane P.J., 2003, Emerging issues in corporate entrepreneurship, Journal of Management, vol. 29.

Dyduch W., 2008, Pomiar przedsiębiorczości organizacyjnej, Wydawnictwo Akademii Ekonomicznej im. Karola Adamieckiego w Katowicach, Katowice 2008.

Dyduch W., 2013, Twórcza strategia, Wydawnictwo Uniwersytetu Ekonomicznego w Katowicach, Katowice.

Eggers J.P., Kaplan S., 2009, Cognition and renewal: Comparing CEO and organizational effects on incumbent adaptation to technical change, Organization Science, vol. 20.

Eisenhardt K.M., Martin J., 2000, Dynamic capabilities: What are they?, Strategic Management Journal, vol. 21.

Eisenhardt K.M., Tabrizi B.N., 1995, Accelerating adaptive processes: Product innovation in the global computer industry, Administrative Science Quarterly, vol. 40.

Floyd S.W., Lane P.J., 2000, Strategizing throughout the organization: Managing role conflict in strategic renewal, Academy of Management Review, vol. 25.

Guth W.D., Ginsberg A., 1990, Guest editor's introduction: Corporate entrepreneurship, Strategic Management Journal, vol. 11.

Helfat C.E., Raubitschek R.S., 2000, Product sequencing: Co-evolution of knowledge, capabilities and products, Strategic Management Journal, vol. 21.

Huff J.O., Huff A.S., Thomas H., 1992, Strategic renewal and the interaction of cumulative stress and inertia, Strategic Management Journal, vol. 13.

Karpacz J., 2011, Determinanty odnowy strategicznej potencjału małych i średnich przedsiębiorstw. Aspekty teoretyczne i wyniki badań empirycznych, Oficyna Wydawnicza SGH, Warszawa. 
Kim H.E., Pennings J.M., 2009, Innovation and strategic renewal in mature market: A study of the tennis racket industry, Organization Science, vol. 20 .

Knott A.M., Posen H.E., 2009, Firm R\&D behaviour and evolving technology in established industries, Organization Science, vol. 20.

Levinthal D.A., March J.G., 1993, The myopia of learning, Strategic Management Journal, vol. 14.

Lichtenstein B.B., Dooley K.J., Lumpkin G.T., 2006, Measuring emergence in the dynamic of new venture creation, Journal of Business Venturing, vol. 21.

Mezias S.J., Glynn M.A., 1993, The three faces of corporate renewal: Institution, revolution, and evolution, Strategic Management Journal, vol. 14.

Miles M.P., Covin J.G., 2002, Exploring the practice of corporate venturing: Some common forms and their organizational implications, Entrepreneurship. Theory and Practice, vol. 26, s. 21-40.

Pappas J.M., Wooldridge B., 2007, Middle managers' divergent strategic activity: An investigation of multiple measures of network centrality, Journal of Management Studies, vol. 44.

Poskela J., Martinsuo M., 2009, Management control and strategic renewal in the front end of innovation, Journal of Product Innovation Management, vol. 26.
Sáez-Martínez F.J., González-Moreno Á., 2011, Strategic renewal, cooperation, and performance: A contingency approach, Journal of Management and Strategy, vol. 2, no 4.

Sharma P., Chrisman J.J., 1999, Toward a reconciliation of the definitional issues in the field of corporate entrepreneurship, Entrepreneurship. Theory and Practice, vol. 23.

Simons R., 1994, How new top managers use control systems as levers of strategic renewal, Strategic Management Journal, vol. 15.

Teng B-S., 2007, Corporate entrepreneurship activities through strategic alliances: A Resource-based approach toward competitive advantage, Journal of Management Studies, vol. 44

Yang J., 2012, Innovation capability and corporate growth: An empirical investigation in China, Journal of Engineering and Technology Management, vol. 29 .

Zahra S.A., 1995, Corporate entrepreneurship and company performance: The case of management leveraged buyouts, Journal of Business Venturing, vol. 10.

Zahra S.A., 1993, Environment, corporate entrepreneurship and financial performance: A taxonomic approach, Journal of Business Venturing, vol. 8.

Zahra S.A., 1996, Governance, ownership, and corporate entrepreneurship: The moderating impact of industry technological opportunities, Academy of Management Journal, vol. 39. 